\title{
Habitat specialization and climate affect arthropod fitness: a comparison of generalist vs. specialist spider species in Arctic and temperate biomes
}

\author{
CAMILLE AMELINE ${ }^{1,2 *}$, CHARLÈNE PUZIN ${ }^{1}$, JOSEPH J. BOWDEN ${ }^{3,4}$, KEVIN LAMBEETS $^{5}$, \\ PHILIPPE VERNON ${ }^{6}$ and JULIEN PÉTILLON ${ }^{1}$ \\ ${ }^{1}$ Université de Rennes 1, EA 7316, 263 Avenue du Général Leclerc, CS 74205, 35042 Rennes Cedex, \\ France \\ ${ }^{2}$ University of Basel, Zoological Institute, Evolutionary Biology, Vesalgasse 1, 4051 Basel, Switzerland \\ ${ }^{3}$ Arctic Research Centre, Aarhus University, Ny Munkegade 114, bldg. 1540, DK-8000 Aarhus C, \\ Denmark \\ ${ }^{4}$ Canadian Forest Service - Atlantic Forestry Centre, PO Box 960, 26 University Drive, Corner Brook, NL, \\ Canada, A2H 6J3 \\ ${ }^{5}$ Terrestrial Ecology Unit, Ghent University, K. L. Ledeganckstraat 35, B-9000 Ghent, Belgium \\ ${ }^{6}$ Université de Rennes 1, UMR 6553 CNRS, Station Biologique de Paimpont, 35380 Paimpont, France
}

Received 1 December 2016; revised 1 February 2017; accepted for publication 1 February 2017

\begin{abstract}
Life history trade-offs are a key notion in evolutionary biology, notably for understanding how selection shapes the diversity of traits among species. Despite the frequent study of such trade-offs, few studies synchronously investigate the effects of multiple factors, such as niche specialization and adaptation to harsh environments. We compared reproduction (fecundity and egg quality) in two sympatric couples (one habitat generalist and one specialist) of congeneric wolf spider species, in both Arctic and temperate habitats. We found that specialist species at both latitudes invested more in clutch size than did generalist species. We interpret this result as an optimization of clutch production. In the Arctic, the specialist was able to invest in fecundity with increasing body size at a much higher rate than the generalist species. In the temperate habitat, both species showed similar strategies: they increased quantity and quality of offspring relative to body size at the same rate. These results are consistent with the hypothesis that Arctic species must develop distinct strategies in order not to overlap each other's ecological niches as a consequence of limited food resources or niche space. We emphasize the need to test the role of plasticity and environmentally mediated effects of competition on arthropod fitness.
\end{abstract}

ADDITIONAL KEYWORDS: body size - competition - latitude - life history - Lycosidae - Pardosa spp. reproductive trade-offs - sympatric species.

\section{INTRODUCTION}

There is a stunning diversity of life histories among species. This diversity can be explained by life history theory, which proposes that life history trade-offs are shaped by natural selection in order to maximize fitness with a fixed amount of available resources for allocation to reproduction, or any other component at any given time (Stearns, 1992; Roff, 2002). In this context, a reproductive quality/quantity trade-off in

*Corresponding author. E-mail: cameline8@gmail.com the investment of resources related to female body size is often revealed (Brown, Sanford \& Swerdon, 2003; Skow \& Jakob, 2003; Bowden \& Buddle, 2012a). With reproduction being such a large investment, it follows that trade-offs between quality and quantity are particularly relevant under harsh environmental conditions (e.g. limited resources due to competition or adverse abiotic conditions; Roff, 2002). In such sub-optimal conditions, the mother should increase the quality of her offspring while decreasing the number produced (Roff, 1993). Indeed, offspring fitness increases with investment per individual (Smith \& 
Fretwell, 1974). This explanation proposes that habitat constraints drive reproductive trade-offs, which are frequently studied along geographical or environmental gradients (Albuquerque, Tauber \& Tauber, 1997; Reed \& Nicholas, 2008; Liao, Lu \& Jehle, 2014). In the context of community ecology, coexistence of similar/related species could be mediated by differing life history strategies (Tokeshi, 1999). Hence, a natural experiment taking advantage of congeneric coexisting species in environments differing in harshness could provide insight into the combined effects of abiotic and biotic factors on reproductive trade-offs.

In this study, we assessed and compared reproductive trade-offs between species contrasting in habitat specialization between two climates differing in harshness. In order to do so, we compared the relationship between female body size and reproductive traits (fecundity and egg quality) in two sympatric couples of congeneric wolf spider species (Lycosidae) composed of one generalist and one specialist collected from the Arctic (south-west Greenland) and a temperate habitat in Belgium and in the Netherlands. We used egg number and volume as proxies for fecundity and offspring quality, respectively. For Arctic wolf spider species, clutch size is considered as a proxy for fecundity because only one clutch per lifetime is likely produced (Bowden \& Buddle, 2012b). In temperate Pardosa species, however, we acknowledge that some species produce one clutch per lifetime (Harvey, Nellist \& Telfer, 2002; Puzin et al., 2011), while others can produce up to two clutches per lifetime (Vlijm, Kessler \& Richter, 1963; Alderweireldt \& Maelfait, 1988; Bonte \& Maelfait, 2001). The latter clutch is produced at a distinctive period of time, well after the first, with clutches typically being separated by several weeks (Bonte \& Maelfait, 2001). Offspring quality was approximated with egg volume, as bigger eggs result in bigger and fitter offspring (Fox \& Czesak, 2000). Female wolf spiders carry their egg sac tethered to their abdomen, allowing for the collection of data on the individual along with data on reproductive traits (e.g. Hendrickx et al., 2003; Pétillon et al., 2009). Using four congeneric species from two latitudes, we aim to evaluate three hypotheses about life history strategies between two groups of species differing in habitat specialization and geographic location.

Based on the literature related to life history theory and empirical work on wolf spiders, we make the following hypotheses: (1) fecundity will increase with female body size while egg quality will vary independently of female body size in all four species, as female size is related to fecundity, and female condition to offspring quality (Simpson, 1993; Puzin et al., 2011; Bowden \& Buddle, 2012a); (2) specialist species will have a relatively higher reproductive output than generalist species because they are supposed to be better adapted to their habitat; a higher reproductive output being reflected by the ability to invest in clutch size more than in egg volume (e.g. Pétillon et al., 2009). Indeed, we suppose that if better adapted to their environment, the offspring of specialists would not need as much resources as the generalists' offspring; (3) finally, egg quantity/quality trade-offs are expected to be stronger in the Arctic than in the temperate habitat as trade-offs are more often detected in harsh habitats due to limited resources (Roff, 2002).

\section{MATERIAL AND METHODS}

FOCAL SPECIES AND SITES

We hand collected four different species of wolf spiders (Pardosa spp.) as two couples of sympatric species in distinct habitats, each couple being composed of one generalist and one specialist species. Pardosa hyperborea (Thorell, 1872) $(n=60)$, generalist and $P$. furcifera (Thorell, 1875) $(n=60)$, specialist were collected in an Arctic habitat, whereas $P$. amentata (Clerck, 1757) $(n=$ $65)$, generalist and P. agricola (Thorell, 1856) $(n=68)$, specialist were collected in a temperate habitat. Details of the species' ecology are given in Table 1. As stated in Table 1, we considered P. hyperborea as a generalist species and $P$. furcifera as a specialist species. Indeed, in a previous study (unpublished data), we could abundantly find the former in three locations in south-west Greenland, from 0 to about $700 \mathrm{~m}$ a.s.l., although we could only find the latter in one of these locations, abundantly at sea level (60 individuals sampled) but very rarely at high elevation (three individuals found at $200 \mathrm{~m}$ a.s.l.).

Collections were conducted in dwarf shrub heath habitats in Kobbefjord (64.117N, 51.350W), Greenland, from 5 to 10 July 2013, and along the river banks of the Common Meuse separating Belgium and the Netherlands (51.000N, 5.800E) on 1 June 2005 and 8 June 2006. From each site, a minimum of 30 females with egg sacs were collected for both populations within the same relatively small area $\left(\sim 1 \mathrm{~km}^{2}\right)$ and preserved individually in $70 \%$ alcohol. Further sampling details are presented in Supporting Information Table S1.

\section{MEASUREMENTS IN LABORATORY}

Fecundity and egg quality were measured using clutch size and egg volume as proxies, respectively. Measurements were done to the nearest $0.01 \mathrm{~mm}$ via digital photographs using EUROMEX ImageFocus v3.0 (Arctic samples) or directly with a measuring ocular using a WILD M5 stereomicroscope (temperate samples). For each individual, we measured the width of the prosoma, and counted the eggs in the sac. We also measured mean length and width of ten eggs 
Table 1. Description of the four species collected on the field

\begin{tabular}{|c|c|c|c|c|}
\hline Species & Description & Distribution & Elevation (m a.s.l.) & $\begin{array}{l}\text { Habitat spe- } \\
\text { cialization }\end{array}$ \\
\hline P. hyperborea & Thorell, 1872 & Holarctic $^{[20]}$ & $100-1360^{[3,4,13,14,15,16,17]}$ & Generalist \\
\hline$P$. furcifera & Thorell, 1875 & $\begin{array}{l}\text { Canada, Alaska, Greenland, } \\
\text { Iceland }^{[20]} \text { : trans-Nearctic } \\
\text { arcto-alpine range }^{[11]}\end{array}$ & $0-1360^{[14,15,16]}$ & Specialist \\
\hline P. amentata & Clerck, 1757 & Europe, Russia ${ }^{[20]}$ & Up to $2300^{[3,8,17,19]}$ & Generalist \\
\hline P. agricola & Thorell, 1856 & Europe to Kazakhstan ${ }^{[20,19]}$ & $\begin{array}{l}\text { Not in elevated regions } \\
0-500[18,19]\end{array}$ & Specialist \\
\hline Species & \multicolumn{4}{|l|}{ Found habitats } \\
\hline P. hyperborea & \multicolumn{4}{|c|}{$\begin{array}{l}\left.\text { Open forests and moors }{ }^{[19]} \text {, birch wood }{ }^{[2,16]} \text {, sphagnum bogs (in boreal zones }{ }^{[9]}\right) \text {, low-lying spruce } \\
\text { forests, rocky hillsides, among lichens in Arctic and alpine tundra and on needle mats in } \\
\text { forests of jack pine, black spruce and balsam fir }{ }^{[5]} \text {, transition boreal forest to Arctic tun- } \\
\text { dra }^{[15]} \text {, subarctic pine forest area, birch woods, bogs and treeless fell } \mathrm{s}^{[16]}\end{array}$} \\
\hline P. furcifera & \multicolumn{4}{|c|}{$\begin{array}{l}\text { Spruce-pine forests, in willow clumps near the timberline, and on moss and stones in alpine } \\
\text { tundra }{ }^{[5]} \text {, subarctic pine forest area, birch woods, bogs/heath transitions and treeless fells }{ }^{[15,16]}\end{array}$} \\
\hline P. amentata & \multicolumn{4}{|c|}{$\begin{array}{l}\text { Widespread in damp habitats }{ }^{[6,19,21]}, \text { lowlands }{ }^{[12]} \text { and mountains above the forest-line } e^{[7]} \text {, tun- } \\
\text { dra }^{[17]} \text {, rich grassland, poor grassland, ash woodland }{ }^{[10]} \text {, marshy hollow with stream and } \\
\text { willow scrub above the birch tree-line }{ }^{[3]}\end{array}$} \\
\hline P. agricola & \multicolumn{4}{|c|}{ In open, sandy terrain, in stony banks of lakes and watercourses ${ }^{[1,19]}$, on wet moss by the shore ${ }^{[3]}$} \\
\hline
\end{tabular}

References: 1: Vlijm, 1971; 2: Bengston et al., 1976; 3: Ashmole \& Planterose, 1979; 4: Koponen, 1987; 5: Dondale \& Redner, 1990; 6: Buchar, 1993; 7: Deltshev, 1995; 8: Logunov, Marusik \& Koponen, 1998; 9: Koponen, 2002; 10: Cameron, Johnston \& McAdam, 2004; 11: Marusik, Böcher \& Koponen, 2006; 12: Fet \& Popov, 2007; 13: Hammel \& Nickel, 2008; 14: Høye \& Hammel, 2010; 15: Bowden \& Buddle, 2010; 16: Koponen, 2011; 17: Hein et al., 2014; 18: British Arachnological Society, 2015; 19: Nentwig et al., 2015; 20: World Spider Catalog, 2015.

randomly taken from each clutch. Mean egg volume was then calculated as the mean of their volume using the formula:Volume $=\frac{\pi}{6} \times$ length $\times$ width $^{2}\left(\mathrm{~mm}^{3}\right)$ following Hendrickx \& Maelfait (2003). In the situation where eggs had hatched inside the egg sac $(n=34$ out of 65 P. amentata females and $n=22$ out of 68 P. agricola females), we measured the prosoma of ten postembryonic individuals (i.e. nymphs) as a proxy for egg volume. Since a female was always collected with an intact egg sac, we assume not to have lost any postembryonic individual.

As sampling was not necessarily done at the same stage of egg development, we considered mean egg volume as a less reliable trait than clutch size. We consequently did not use a variable connecting clutch size and mean egg volume, but instead used them separately as response variables in our models.

\section{ANALYSES}

We assessed the effect of body size on reproductive traits (clutch size and mean egg volume or mean body size of postembryonic individuals) for the two couples of sympatric species.

The distribution of measurements was plotted and normality was tested via a distribution histogram and a quantile-quantile plot. All measured variables were normally distributed. Comparisons were performed via one-tailed $t$-tests, ANOVA or Kruskal-Wallis models after testing for homoscedasticity. Correlations between traits were assessed with Pearson tests.

We used ANCOVA models for the analyses and Linear Least Squares Regressions (LLSR) for the graphical representations of the significant effects in the models. For each initial model, we selected the model with the lowest Akaike Information Criterion (package 'MASS': Venables \& Ripley, 2002). The significance of explanatory variables and factors was then tested using ANOVA and type III sums of squares (package 'car': Fox \& Weisberg, 2011), that is without taking into account the order of the explanatory variables/factors. All non-significant interactions and factors were excluded from the final models. Finally, we tested if the residuals of the final model were normally distributed and this was done via a distribution histogram and a quantile-quantile plot. A significant effect is referred in the text as an 'effect of the variable/factor on the other variable'.

All means are presented with standard deviation (package 'RVAideMemoire': Hervé, 2015) and all statistics were conducted with the $\mathrm{R}$ v. 3.1.3 software ( $\mathrm{R}$ Development Core Team, 2014) and Microsoft Excel (2013). 


\section{RESULTS}

\section{COMPARISON OF SYMPATRIC SPECIES IN THE ARCTIC BIOME}

The mean body size of the generalist species ( $P$. hyperborea) was $1.85 \pm 0.13 \mathrm{~mm}(n=60)$, while the mean body size of the specialist species ( $P$. furcifera) was $3.05 \pm 0.14 \mathrm{~mm}(n=59$, one specimen was dry and consequently not usable). Our results show an effect of species and a positive effect of female body size on clutch size, which differed between the two species (Table 2, Fig. 1A). Indeed, the specialist species increased clutch size at a higher rate than the generalist species when body size increased, as the regression slopes were 81.93 and 36.63, respectively (Fig. 1A). Mean clutch size of $P$. hyperborea and $P$. furcifera was $39 \pm 6(n=60)$ and $91 \pm 19(n=59)$, respectively and was significantly higher in $P$. furcifera (one-tailed $t$-test, $t=19.48$, d.f. $\left.=69.76, P<2.2 \times 10^{-16}\right)$. Our results showed an effect of species on mean egg volume, but no effect of female body size (Table 2). Mean egg volume for $P$. hyperborea and $P$. furcifera was $0.37 \pm 0.04 \mathrm{~mm}^{3}$ $(n=60)$ and $0.50 \pm 0.04 \mathrm{~mm}^{3}(n=59)$, respectively and was significantly higher for $P$. furcifera (one-tailed $t$-test, $t=16.45$, d.f. $\left.=117, P<2.2 \times 10^{-16}\right)$.

\section{COMPARISON OF SYMPATRIC SPECIES IN THE TEMPERATE BIOME}

The mean body size of the generalist ( $P$. amentata) was $2.63 \pm 0.15 \mathrm{~mm}(n=65)$, while the mean body size of the specialist $(P$. agricola) was $2.19 \pm 0.13 \mathrm{~mm}(n=68)$. There was an effect of species and a positive effect of female body size on clutch size (Table 2, Fig. 1B). This effect of body size on clutch size was the same for the two species, which means that contrary to the situation in the Arctic, both specialist and generalist species increased clutch size with increasing body size at the same rate $(63.17$, Fig. 1B). Mean clutch size in $P$. amentata and $P$. agricola was $56 \pm 16(n=65)$ and $46 \pm 11(n=68)$, respectively and was significantly higher in $P$. amentata (one-tailed $t$-test, $t=-4.23$, d.f. $\left.=115.57, P=2.32 \times 10^{-5}\right)$. Our results only showed an effect of species on mean egg volume, but no effect of body size was detected (Table 2). Mean egg volume in $P$. amentata and $P$. agricola was $0.44 \pm 0.07 \mathrm{~mm}^{3}$ $(n=31)$ and $0.35 \pm 0.05 \mathrm{~mm}^{3}(n=46)$, respectively and was significantly higher in P. amentata (one-tailed $t$-test, $t=-6.44$, d.f. $\left.=71.29, P=5.94 \times 10^{-9}\right)$. There was a positive effect of female body size on the mean size of the postembryonic individuals, and this effect was the same for both species (Table 2, Supporting Information Fig. S1). Mean size of the postembryonic individuals was $0.54 \pm 0.04 \mathrm{~mm}(n=34)$ and $0.49 \pm 0.05 \mathrm{~mm}$ $(n=22)$ for $P$. amentata and $P$. agricola, respectively and was significantly higher in $P$. amentata (one-tailed $t$-test, $t=3.98$, d.f. $=54, P=0.00010)$.

\section{DISCUSSION}

In this study, we assessed the combined effects of environmental constraints and habitat specialization on reproductive output in wolf spider species (Lycosidae). We had three hypotheses: (1) fecundity should increase with female body size while egg quality would vary independently, (2) specialist species should invest more in fecundity than generalist species and (3)

Table 2. ANCOVA analyses details of the effect of body size on reproductive output. Values are given for final models

\begin{tabular}{|c|c|c|c|c|c|c|c|c|c|}
\hline & Initial model & $\begin{array}{l}\text { Response } \\
\text { variable }\end{array}$ & $F$ & d.f. & $R^{2}$ & $P$ & $\begin{array}{l}\text { Explanatory } \\
\text { variables }\end{array}$ & $F$ & $P$ \\
\hline \multirow{4}{*}{$\begin{array}{c}\text { In Kobbefjord at } \\
\text { sea level: effect } \\
\text { of body size on } \\
\text { reproductive } \\
\text { traits, sympatry } \\
\text { of } P \text {. hyperborea } \\
\text { and } P \text {. furcifera }\end{array}$} & \multirow[t]{3}{*}{$\begin{array}{l}\text { Clutch size } \sim \\
\text { species*body size }\end{array}$} & \multirow[t]{3}{*}{ Clutch size } & \multirow[t]{3}{*}{219.40} & \multirow[t]{3}{*}{115} & \multirow[t]{3}{*}{0.85} & \multirow[t]{3}{*}{$<2.2 .10^{-16}$} & Species & 9.45 & 0.0026 \\
\hline & & & & & & & Body size & 56.83 & $1.19 \times 10^{-11}$ \\
\hline & & & & & & & $\begin{array}{l}\text { Species: } \\
\text { body size }\end{array}$ & 7.43 & 0.0074 \\
\hline & $\begin{array}{l}\text { Mean egg volume } \\
\text { species*body size }\end{array}$ & $\begin{array}{l}\text { Mean egg } \\
\text { volume }\end{array}$ & 270.6 & 117 & 0.70 & $<2.2 .10^{-16}$ & Species & 270.56 & $5.44 \times 10^{-7}$ \\
\hline \multirow{4}{*}{$\begin{array}{l}\text { In Belgium-the } \\
\text { Netherlands at } \\
\text { sea level: effect } \\
\text { of body size on } \\
\text { reproductive } \\
\text { traits, sympatry } \\
\text { of } P \text {. amentata } \\
\text { and } P \text {. agricola }\end{array}$} & \multirow[t]{2}{*}{$\begin{array}{l}\text { Clutch size } \\
\text { species*body size }\end{array}$} & \multirow[t]{2}{*}{ Clutch size } & \multirow[t]{2}{*}{57.09} & \multirow[t]{2}{*}{130} & \multirow[t]{2}{*}{0.46} & \multirow[t]{2}{*}{$<2.2 .10^{-16}$} & Species & 24.01 & $2.80 \times 10^{-06}$ \\
\hline & & & & & & & Body size & 84.41 & $8.26 \times 10^{-16}$ \\
\hline & $\begin{array}{l}\text { Mean egg volume } \\
\text { species*body size }\end{array}$ & $\begin{array}{c}\text { Mean egg } \\
\text { volume }\end{array}$ & 43.15 & 85 & 0.33 & $3.85 \times 10^{-09}$ & Species & 43.15 & $3.85 \times 10^{-09}$ \\
\hline & $\begin{array}{l}\text { Mean baby size } \\
\text { species*body size }\end{array}$ & $\begin{array}{l}\text { Mean baby } \\
\text { size }\end{array}$ & 19.88 & 45 & 0.29 & $5.44 \times 10^{-05}$ & Body size & 19.88 & $5.44 \times 10^{-05}$ \\
\hline
\end{tabular}

Significant $P$-values are highlighted in bold. 


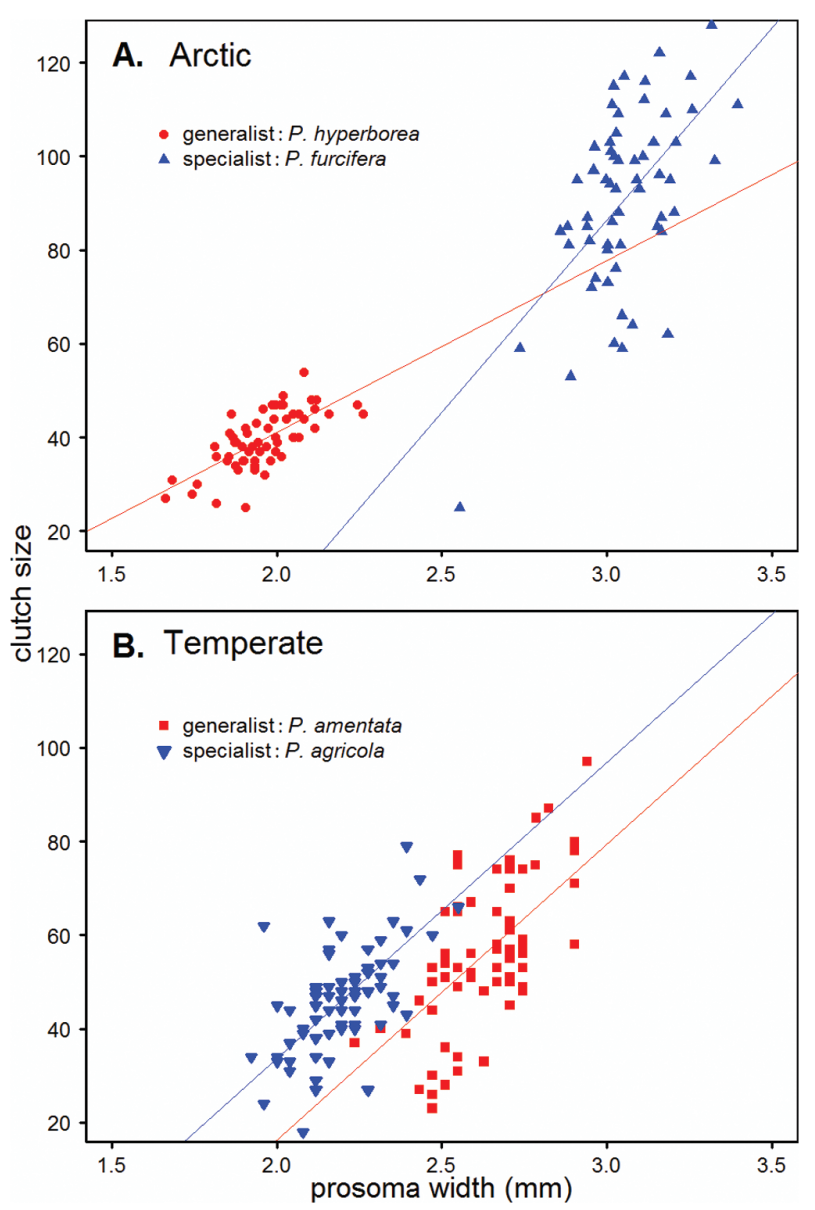

Figure 1. Clutch size depending on female body size. (A) In the Arctic. $P$. hyperborea (LLSR, clutch size = $-32.19+36.63^{*}$ prosoma width, $F=56.11$, 58 d.f., $\left.R^{2}=0.48, P=4.4 \times 10^{-10}\right)$, $P$. furcifera (LLSR, clutch size $=$ $-159.28+81.93^{*}$ prosoma width, $F=30.49,57$ d.f., $R^{2}=0.34$, $\left.P=8.6 \times 10^{-7}\right)$. (B) In a temperate habitat. ANCOVA, clutch size $=-92.70(-17.42$ for $P$. amentata $)+63.17^{*}$ prosoma width, $F=57.09,130$ d.f., $R^{2}=0.46, P<2.2 \times 10^{-16}$.

reproductive trade-offs are expected to be stronger in the Arctic where the conditions are harsher. We found that larger females produced more offspring independently of species or location. We also found that specialist species invested more in clutch size than did generalist species. Moreover, our results indicate that, in the Arctic, species developed distinct strategies likely in order not to overlap each other's ecological niches as a consequence of limited food resources, contrary to temperate species which presented similar reproductive strategies.

\section{ADVANTAGE OF A LARGER BODY SIZE}

In accordance with our first hypothesis, independently of species or location, fecundity (clutch size) increased with body size while egg quality (egg volume) varied independently of female body size. For temperate species, postembryonic size, but not egg volume, increased with female body size and we discuss this result in the third part of the discussion. These results are coherent with other findings in wolf spiders where fecundity, but not egg quality, increased with body size (Simpson, 1993; Pétillon et al., 2009; Puzin et al., 2011). Indeed, egg quality appears to be better explained by body condition (Bowden \& Buddle, 2012a). These studies showed that having a larger body size is an advantage for the female which may consequently increase her fecundity, and also often offspring quality (Marshall \& Gittleman, 1994). One experimental approach to test this hypothesis on a functional basis would be to impose dietary restriction on the females (Adler et al., 2013) or to manipulate their energy storage (Cox, Lovern \& Calsbeek, 2014). Last, we know that the adult body size and reproductive output of Arctic wolf spiders may fluctuate according to snowmelt timing, and this occurs in space and time (Høye et al., 2009; Bowden et al., 2015), creating differing activity periods in which to obtain resources. Hence, we cannot completely discount the possibility that the timing of specimen collection (i.e. different years) could influence our results. We do, however, presume the effect size to be greater than the year of collection and, ultimately, that the same pattern would hold as with other biogeographical phenomena (e.g. Ernst \& Buddle, 2015).

\section{BETTER ADAPTATION OF SPECIALISTS TO THEIR ENVIRONMENT}

In the Arctic, clutch size of the specialist P. furcifera increased with body size at a higher rate than the generalist P. hyperborea (Fig. 1A); whereas in the temperate habitat, clutch size of both species increased with body size at the same rate but the specialist $P$. agricola invested more in clutch size for the same body size (Fig. 1B). This confirms our second hypothesis that specialist species are better adapted to their environment and are therefore able to invest more into fecundity (cf. Pétillon et al., 2009).

Two main differences between the Arctic species are striking when observing body size and niche specialization. Indeed, the specialist species $P$. furcifera was, on average, 1.6 times larger than the generalist species $P$. hyperborea. Consequently, $P$. furcifera is able to increase its fecundity more efficiently than $P$. hyperborea. This result suggests that $P$. furcifera may occupy a habitat of better fit, given its niche requirements. However, while $P$. furcifera might be better adapted to its environment as a habitat specialist, our findings could also be due to the fact that larger individuals are able to invest more energy in fecundity and quality 
of progeny (Marshall \& Gittleman, 1994). These ideas about differences in life history investments between specialists and generalists should be further investigated using other species and groups, particularly to gain a better understanding of the relation between body size and reproductive output. In the temperate habitat, and contrary to the previous case, the specialist species was significantly smaller. Indeed, on average, body size of $P$. agricola was 1.2 times smaller than $P$. amentata. Consequently, this finding adds support to the specialist adaptation hypothesis. Such an adaptation could be linked to physical constraints (Lambeets, Maelfait \& Bonte, 2008), to feeding specialization (Roslin \& Salminen, 2008) or to physiological constraints (Pétillon et al., 2011). These two species were, however, collected in a riparian environment where the temperature variability is high and the river is prone to unpredictable inundation during the reproductive season (Lambeets et al., 2008). We hence hypothesize that adaptation of the specialist is mainly linked to physical constraints, namely rapid changes in water level and temperature.

\section{HIGHER COMPETITION IN THE ARCTIC}

We found that the specialist and the generalist species in the temperate habitat adopted similar strategies, while the Arctic species did not. This could be related to the relatively harsher climatic conditions of the Arctic, which may ultimately result in resource limitation. Intraguild predation, a unique variety of competition common in spiders, is believed to be a foraging strategy that helps overcome the effects of limited resources (Wise, 2006). It has been shown in P. palustris, for example, that cannibalism increased as a consequence of food limitation (Rickers \& Scheu, 2005). Further experimentation could compare this phenomenon among niche specializations and habitats. We propose that in the Arctic, the relative simplicity of the environment would also increase inter-specific competition, due to a limited number of ecological niches, leading to niche overlap. In our case, the lack of alternative food resources and the adaptation of the specialist species to local conditions could be synergic factors leading to inter-specific competition, potentially reflected by differential resource acquisition, differential female fecundity and differential search ability (Reitz \& Trumble, 2002).

The size of postembryonic individuals increased significantly with female body size in both of the temperate species, but the volume of the eggs did not in the Arctic species. As mentioned above, the riparian environment of the temperate species also presents harsh conditions due to irregular flooding and extreme temperatures but it is extremely prey-rich (e.g. for lycosids: Paetzold, Schubert \& Tockner, 2005), which suggests that food is not a limiting factor in the temperate environment. Hence, both temperate species were even able to increase simultaneously quantity and quality of offspring, which supports our third hypothesis of a non-food-limited habitat.

In addition, as stated in the introduction, we must keep in mind that temperate species might produce more than one clutch per lifetime. However, given the relatively narrow window of collection at each locality, it is unlikely that second clutches were collected in high enough frequency to significantly influence the variation in our data. Total reproductive output is hard to assess on relatively small spider species given that individual tracking is almost impossible. Moreover, in our case, data acquisition requires field collected females, hence totally impeding individual tracking. We advocate for further investigation of the additive or multiplicative effects that habitat specialization and elevation/latitude play in driving life history variation. Moreover, laboratory based experiments would help elucidate the relative roles of plasticity and adaptation in these patterns. We conclude that habitat specialization as well as the environment can have significant impacts on reproductive investment between congeneric species.

\section{ACKNOWLEDGEMENTS}

This work was part of the SPACEWOLF project (Spatial gradients in physiological adaptation and life history traits of Arctic wolf spiders) led by Julien Pétillon and Philippe Vernon, and funded by INTERACT: International Network for Terrestrial Research and Monitoring in the Arctic. Cyril Courtial helped sample the Greenland populations. Viki Vandomme and Dries Bonte helped sample the Belgium populations and the measurements were performed by Davy Bosman and Kim De Crem for their Bachelor thesis, all from Ghent University, Department of Biology, Terrestrial Ecology Unit (TEREC). We thank three anonymous reviewers for their helpful comments on the manuscript.

\section{SHARED DATA}

Data available from the Dryad Digital Repository: Amelin et al., (2017).

\section{REFERENCES}

Adler MI, Cassidy EJ, Fricke C, Bonduriansky R. 2013. The lifespan-reproduction trade-off under dietary restriction is sex-specific and context-dependent. Experimental Gerontology 48: 539-548. 
Albuquerque GS, Tauber MJ, Tauber CA. 1997. Lifehistory adaptations and reproductive costs associated with specialization in predacious insects. Journal of Animal Ecology 66: 307-317.

Alderweireldt M, Maelfait JP. 1988. Life cycle, habitat choice and distribution of Pardosa amentata (Clerck, 1757) in Belgium (Araneae, Lycosidae). Bulletin de la Société scientifique de Bretagne 59: 7-15.

Ameline C, Puzin C, Bowden JJ, Lambeets K, Vernon P, Pétillon J. 2017. Data from: Habitat specialisation and climate affect arthropod fitness: a comparison of generalist vs. specialist spider species in Arctic and temperate biomes. Dryad Digital Repository. http://dx.doi.org/10.5061/dryad.gm21j

Ashmole N, Planterose B. 1979. Spiders from arctic Fennoscandia. Norwegian Journal of Entomology 26: 26-30.

Bengston SA, Nilsson A, Nordstrom S, Rundgren S. 1976. Species composition and distribution of spiders (Aranea) in Iceland. Norwegian Journal of Entomology 23: 35-39.

Bonte D, Maelfait JP. 2001. Life history, habitat use and dispersal of a dune wolf spider (Pardosa monticola (Clerck, 1757) Lycosidae, Araneae) in the Flemish coastal dunes (Belgium). Belgian Journal of Zoology 131: 145-157.

Bowden JJ, Buddle CM. 2010. Determinants of grounddwelling spider assemblages at a regional scale in the Yukon Territory, Canada. Ecoscience 17: 287-297.

Bowden JJ, Buddle CM. 2012a. Life history of tundradwelling wolf spiders (Araneae: Lycosidae) from the Yukon Territory, Canada. Canadian Journal of Zoology 90: 714-721.

Bowden JJ, Buddle CM. 2012b. Egg sac parasitism of Arctic wolf spiders (Araneae: Lycosidae) from northwestern North America. Journal of Arachnology 40: 348-350.

Bowden JJ, Hansen RR, Olsen K, Høye TT. 2015. Habitatspecific effects of climate change on a low-mobility Arctic spider species. Polar Biology 38: 559-568.

British Arachnological Society. 2015. Spider and harvestman recording scheme website, the national recording schemes for spiders and harvestmen in Britain. Available at: http://srs.britishspiders.org.uk

Brown CA, Sanford BM, Swerdon RR. 2003. Clutch size and offspring size in the wolf spider Pirata sedentarius (Araneae, Lycosidae). Journal of Arachnology 31: 285-296.

Buchar J. 1993. Biogeographical and ecological relations of wolf spiders in Czechoslovakia and in Central Europe. Bolletino Dell'Accademia Gioenia Di Scienze Naturali 26: 27-34.

Cameron A, Johnston RJ, McAdam J. 2004. Classification and evaluation of spider (Araneae) assemblages on environmentally sensitive areas in Northern Ireland. Agriculture, Ecosystems, Environment 102: 29-40.

Cox RM, Lovern MB, Calsbeek R. 2014. Experimentally decoupling reproductive investment from energy storage to test the functional basis of a life-history trade-off. Journal of Animal Ecology 83: 888-898.

Deltshev. 1995. Spiders (Araneae) from the high altitude zone of Rila Mountain (Bulgaria). Berichte des Naturwissenschaftlichen-Medizinischen Verein Innsbruck 82: $217-225$.

Dondale CD, Redner JH. 1990. The wolf spiders, nurseryweb spiders, and lynx spiders of Canada and Alaska:
Araneae:Lycosidae, Pisauridae, and Oxyopidae. Ottawa: Research Branch, Agriculture Canada.

Ernst CM, Buddle CM. 2015. Drivers and patterns of grounddwelling beetle biodiversity across Northern Canada. PLoS One 10: 0122163.

Fet V, Popov A. 2007. Biogeography and ecology of Bulgaria. Dordrecht: Springer

Fox CW, Czesak ME. 2000. Evolutionary ecology of progeny size in arthropods. Annual Review of Entomology 45: 341-369.

Fox J, Weisberg S. 2011. Package car. An $\{R\}$ Companion to applied regression, 2nd edn. Thousand Oaks, CA: Sage.

Hammel JU, Nickel M. 2008. Pardosa hyperborea (Araneae: Lycosidae): a first report from Disko Island (West Greenland), with remarks on the biogeography of the species. Entomologiske Meddelelser 79: 41-47.

Harvey PR, Nellist DR, Telfer MG. 2002. Provisional atlas of British spiders (Arachnida, Araneae), Vol. 1. Huntingdon: Biological Records Centre.

Hein N, Feilhauer H, Finch OD, Schmidtlein S. 2014. Snow cover determines the ecology and biogeography of spiders (Araneae) in alpine tundra ecosystems. Erdkunde 68: 157-172.

Hendrickx F, Maelfait JP. 2003. Life cycle, reproductive patterns and their year-to-year variation in a field population of the wolf spider Pirata piraticus (Araneae, Lycosidae). Journal of Arachnology 31: 331-339.

Hendrickx F, Maelfait JP, Speelmans M, Van Straalen NM. 2003. Adaptive reproductive variation along a pollution gradient in a wolf spider. Oecologia 134: 189-194.

Hervé M. 2015. RVAideMemoire: diverse basic statistical and graphical functions. $R$ package version 0.9-45-2. Available at: https://cran.r-project.org/web/packages/RVAideMemoire/

Høye TT, Hammel J. 2010. Climate change and altitudinal variation in sexual size dimorphism of arctic wolf spiders. Climate Research 41: 259-265.

Høye TT, Hammel JU, Fuchs T, Toft S. 2009. Climate change and sexual size dimorphism in an Arctic spider. Biology Letters 5: 542-544.

Koponen S. 1987. Communities of ground-living spiders in six habitats on a mountain in Quebec, Canada. Ecography 10: 278-285.

Koponen S. 2002. Ground-living spiders in bogs in northern Europe. Journal of Arachnology 30: 262-267.

Koponen S. 2011. Ground-living spiders (Araneae) at polluted sites in the Subarctic. Arachnologische Mitteilungen 40: $80-84$

Lambeets K, Maelfait JP, Bonte D. 2008. Plasticity in floodavoiding behaviour in two congeneric riparian wolf spiders. Animal Biology 58: 389-400.

Liao WB, Lu X, Jehle R. 2014. Altitudinal variation in maternal investment and trade-offs between egg size and clutch size in the Andrew's toad: maternal investment in a toad. Journal of Zoology 293: 84-91.

Logunov D, Marusik Y, Koponen S. 1998. A check-list of the spiders in Tuva, South-Siberia, with analysis of their habitat distribution. Berichte des NaturwissenschaftlichenMedizinischen Verein Innsbruck 85: 125-159. 
Marshall SD, Gittleman JL. 1994. Clutch size in spiders: is more better? Functional Ecology 8: 118-124.

Marusik Y, Böcher J, Koponen S. 2006. The collection of Greenland spiders (Aranei) kept in the Zoological Museum, University of Copenhagen. Arthropoda Selecta 15: 59-80.

Nentwig W, Blick T, Gloor D, Hänggi A. 2015. Spiders of Europe, version of 09.2015. Available at: www.araneae.unibe.ch

Paetzold A, Schubert CJ, Tockner K. 2005. Aquatic terrestrial linkages along a braided-river: riparian Arthropods feeding on aquatic insects. Ecosystems 8: 748-759.

Pétillon J, Lambeets K, Ract-Madoux B, Vernon P, Renault D. 2011. Saline stress tolerance partly matches with habitat preference in ground-living wolf spiders. Physiological Entomology 36: 165-172.

Pétillon J, Puzin C, Acou A, Outreman Y. 2009. Plant invasion phenomenon enhances reproduction performance in an endangered spider. Die Naturwissenschaften 96: 1241-1246.

Puzin C, Acou A, Bonte D, Pétillon J. 2011. Comparison of reproductive traits between two salt-marsh wolf spiders (Araneae, Lycosidae) under different habitat suitability conditions. Animal Biology 61: 127-138.

R Development Core Team. 2014. $R$ : A language and environment for statistical computing Version 3.1.3. Vienna, Austria: R Foundation for Statistical Computing. Available at: http://www.r-project.org

Reed DH, Nicholas AC. 2008. Spatial and temporal variation in a suite of life-history traits in two species of wolf spider. Ecological Entomology 33: 488-496.

Reitz SR, Trumble JT. 2002. Competitive displacement among insects and arachnids. Annual review of entomology 47: 435-465.

Rickers S, Scheu S. 2005. Cannibalism in Pardosa palustris (Araneae, Lycosidae): effects of alternative prey, habitat structure, and density. Basic and Applied Ecology 6: 471-478.
Roff DA. 1993. Evolution of life histories: theory and analysis. New York: Chapman, Hall.

Roff DA. 2002. Life history evolution. Sunderland: Sinauer Associates.

Roslin T, Salminen JP. 2008. Specialization pays off: contrasting effects of two types of tannins on oak specialist and generalist moth species. Oikos 117: 1560-1568.

Simpson MR. 1993. Reproduction in two species of arctic arachnids, Pardosa glacialis and Alopecosa hirtipes. Canadian Journal of Zoology 71: 451-457.

Skow CD, Jakob EM. 2003. Effects of maternal body size on clutch size and egg weight in a pholcid spider (Holocnemus pluchei). Journal of Arachnology 31: 305-308.

Smith CC, Fretwell SD. 1974. Optimal balance between size and number of offspring. American Naturalist 108: 499-506.

Stearns SC. 1992. The evolution of life histories. Oxford University Press.

Tokeshi M. 1999. Species coexistence: ecological and evolutionary perspectives. Malden, UK: Blackwell Science Ltd.

Venables WN, Ripley BD. 2002. Modern applied statistics with $S$, 4th edn. New York: Springer.

Vlijm L. 1971. Some notes about the occurrence of the genus Pardosa (Lycosidae, Araneae) in southern France, Spain and Corsica. Zoologische Mededelingen 45: 281-288.

Vlijm L, Kessler A, Richter CJJ. 1963. The life history of Pardosa amentata (Cl.) (Araneae, Lycosidae). Entomologische Berichten Amsterdam 23: 75-80.

Wise DH. 2006. Cannibalism, food limitation, intraspecific competition, and the regulation of spider populations. Annual Review of Entomology 51: 441-465.

World Spider Catalog. 2015. World Spider Catalog. Natural History Museum Bern, version 17.0. Available at: http://wsc. nmbe.ch

\section{SUPPORTING INFORMATION}

Additional Supporting Information may be found in the online version of this article at the publisher's website:

Table S1. Sampling details of hand collections of Pardosa species. All collections were done at sea level.

Figure S1. Postembryonic size depending on female size in a temperate habitat. ANCOVA, postembryonic individual size $=0.26+0.10^{*}$ prosoma width, $F=19.88,45$ d.f., $R^{2}=0.29, P=5.4 \times 10^{-5}$. 